\title{
Examining International Parity Relations between Kenya and Uganda: A Cointegrated Vector Autoregressive Approach
}

\author{
Ferdinand Okoth Othieno
}

Correspondence: Ferdinand Okoth Othieno, Institute for Capacity Development (ICAD), KCA University, Nairobi, Kenya. E-mail: fokoth@gmail.com

\author{
Received: March 13, 2012 \\ doi:10.5539/ijef.v4n6p132 \\ Accepted: April 6, $2012 \quad$ Published: June 1, 2012 \\ URL: http://dx.doi.org/10.5539/ijef.v4n6p132
}

\begin{abstract}
This paper analyses empirically the purchasing power parity, the uncovered interest parity and the real interest parity (Fisher parity) between Kenya and Uganda. The paper first tests the three parity relations using stationarity tests. Afterwards the study jointly models international parity conditions, namely PPP, RIP and UIP using a Cointegrated Vector Autoregressive approach. From the analysis of the individual parities, there is no evidence that the individual parities hold between the two countries except for RIP. On the other hand the joint VAR model establishes that the Kenya-Uganda inflation rates, interest rates, and the real exchange rate have followed a long-run equilibrium-correcting behavior. The joint Cointegrated VAR analysis reveals that all the endogenous variables explain more than $99.95 \%$ of the VAR model. This indicates a fast correction towards the long run equilibrium of the parity relations. Hence when the three parity relations are jointly modeled, it can be argued that Uganda has shown a tendency to converge to Kenya both in both nominal and real terms.
\end{abstract}

Keywords: purchasing power parity, uncovered interest parity, real interest parity, common currency, cointegrated var, East African community

\section{Introduction}

The ratification of the East African Community (EAC): the regional intergovernmental organization of the Republics of Kenya, Uganda, Tanzania, Rwanda and Burundi, calls for a close examination of the five countries' economic policy decisions that affect the level and stability of prices, long-term interest rates, the fiscal position and the nominal exchange rates.

The EAC aims at widening and deepening co-operation among the partner States in, among others, political, economic and social fields for their mutual benefit. To this end the EAC countries established a Customs Union in 2005, a Common Market in 2010, and are working towards a Monetary Union by 2012 and ultimately a Political Federation. This co-operation among the EAC countries is expected to open up numerous investment and trade opportunities to the member states and individual investors.

The EAC common market protocol creates a free market of more than 130 million people with a combined GDP of about US\$ 72 billion. Within the EAC, Kenya has the strongest economy contributing close to more than 40 percent of EAC's total GDP. Tanzania, Uganda, and Rwanda have very similar income levels of some US\$ 500 per capita, about two thirds of Kenya's income levels. Overall, the EAC region has been a dynamic economic area averaging an annual GDP growth rate of five percent over the last five years.

The question however that arises is whether the EAC economies are ready for the common monetary policy. This in turn raises a number of research questions. For instance (1) do the real GDP per capita, external debt, consumer price index, interest rates for the five East African Community countries move together? (2) to what extent do the EAC countries' GDP respond to shocks arising from the other East African Community Member countries real GDP per capita, external debt, consumer price index and interest rates? (3) to what extent do the EAC countries' real GDP per-capita respond to shocks arising from the external world as captured through the exchange rate against the US dollar? (4) is the level of integration among the five EAC countries as depicted through the responses in (1), (2) and (3) above sufficient to support a common currency area?

This issue has usually been analyzed from the point of view of the optimum currency area theory (Mundell, 1961, McKinnon, 1963, and Kenen, 1969) which weighs the benefits of a monetary union against its costs. A number of empirical studies in this area concentrate on the symmetry of shocks and shock transmission mechanisms in a given country and its potential partners in the monetary union (De Grauwe, 2003). 
Many studies have examined the validity of both the absolute and relative versions of PPP. While there is a large coincidence on the fact that absolute PPP is almost always rejected, the evidence on relative PPP is mixed (Sosvilla-Rivero \& Garcia, 2003). Eiteman, Stonehill and Moffet (2007) gave two general conclusions that can be gathered from studies on PPP. Firstly, PPP holds up well over the very long run but poorly for shorter time periods and secondly, the theory holds better for countries with relatively high rates of inflation and underdeveloped capital markets. However, whether or not such a relationship holds in the long run, it has also not been without controversy in the literature (Cheng, 1999). In addition, there are some studies that used data from developed countries with relatively low rates of inflation but still found strong support for PPP, for example Sarno and Valente (2006) found evidence of PPP for G5 countries and Alba and Papell (2007) for some European countries. These mixed conclusions of previous studies have given impetus for more studies to be conducted on the international parity conditions.

On the basis that Kenya and Uganda are the largest contributors to the EAC GDP, this paper sought to analyze whether Kenya and Uganda have achieved a sufficient degree of convergence. The paper applied a joint modeling of the three parity relations, the purchasing power parity (PPP), the uncovered interest parity (UIP) and the real interest parity (UIP), an approach which is similar to that of Juselius and MacDonald (2004a), who scrutinized the parity relations between Germany and the US and also adopted by Stazka (2008) in his study of the parity conditions between Germany and Poland.

The study covers macroeconomic variables for Kenya and Uganda for a period of fifty years between 1961 and 2010. The macroeconomic variables covered by the study included real GDP per-capita, external borrowing, the spot exchange rate (defined as local currency/US\$), the foreign country CPI, the foreign country lending rate, for the two countries.

The remainder of this paper is organized as follows: Section 2 covers the literature review; Section 3 covers the methodology and the result of empirical analysis and Section 4 includes the discussion of findings, conclusion and recommendation.

\section{Literature Review}

\subsection{International Parity Relations}

The core of international finance theory lies in international parity conditions. International parity relations detail how exchange rates, interest rates and inflation rates are linked in the market. These relationships can be summarized as follows: the first is purchasing power parity (PPP), or the hypothesis that there exists a constant long-run equilibrium real exchange rate; the second is the Fisher Effect (FE), which tests the relationship between difference in inflation rates and difference in nominal interest rates and the third, the International Fisher Effect (IFE), establishes a relationship between real exchange rates and real interest rate differentials. The three parity relations between two economies hold if goods and asset markets of these economies are perfectly integrated, that is when goods and capital are perfectly mobile. If this is the case, the economies in question can form a common currency area without fearing serious turbulence in case of asymmetric shocks.

Covered interest parity is the mechanism through which an equilibrium relationship is established between spot and forward exchange rates, and risk-equivalent domestic and foreign nominal interest rates. This relationship is also sometimes referred to as the interest rate parity theorem or the covered interest arbitrage condition. Empirical tests generally show that the forward rate is not a very good predictor of the level of the future spot rate (it explains about $10 \%$ of the change in the actual future exchange rates). However, evidence is strong that the forward rate does a better job of predicting at least the direction of changes in future spot rates than do about two-thirds of the better known foreign exchange forecasting services, making it one of the better predictors around.

The economic rationale behind the three parities is given by arbitrage on goods and asset markets. Specifically, if goods are perfectly mobile across countries, then arbitrage ensures that their prices - after accounting for expected changes in the value of the various currencies - are ultimately equalized, which is reflected in the PPP condition. Further, if capital is perfectly mobile across countries, then arbitrage ensures that yields on assets of these countries - again after accounting for expected changes in the value of their respective currencies - are also equalized, which is reflected in the UIP. It can be shown that the PPP and the UIP, taken together, imply the RIP (Lambelet \& Mihailov, 2005); in other words, arbitrage on goods and asset markets ultimately leads to an equalisation of real returns on assets. An implication that the three parities hold is, thus, that the goods and asset markets of two economies are to a large extent integrated.

This, in turn, means that these economies can share a currency and a common monetary policy without fearing serious turbulence when large asymmetric shocks occur. Indeed, the probability of such shocks is very low, because 
economies whose markets are integrated also share a common business cycle and usually have similar output structures (Mongelli, 2005).

\subsection{Previous Studies on International Parity Relations}

There exists a lot of empirical literature on the parity conditions being analyzed though in most studies each of the parity conditions is analyzed separately, whereas in this paper they are modeled jointly. This joint modeling approach is originally due to Juselius and MacDonald (2004a), who scrutinized the parity relations between Germany and the US. A similar approach was taken by Stazka (2008), who scrutinized parity relations between Germany and Poland. Essentially, the analysis in this paper is an application of their approach to the Kenya and Uganda scenario.

Stazka's analysis did not find any evidence that the parities, or any linear combinations of them, held for their data set. They identified two long-run equilibrium relations: (1) the relation imposing a long-run homogeneity restriction on the domestic and foreign inflation and the domestic interest rate and (2) the relation that brings together the domestic real interest rate and the foreign inflation. Juselius and MacDonald (2003) found out that the joint modeling of international parity conditions, namely Purchasing Power Parity (PPP) and the Uncovered Interest Parity (UIP), produces stationary relations showing an important interaction between the goods and the capital markets. Franco (2006) found results consistent with those of Juselius and MacDonald (2003).

Frankel (1993) discusses the relationship between the different theories and assumptions, while Meese and Rogoff (1988) probably provides the classic derivation of the relationship between real exchange rates and real interest rates investigated here.

Despite the theoretical and intuitive appeal both of the real exchange rate real-interest rate differential relationship and of its underlying components, the empirical evidence for these propositions (either separately or collectively) has at best been mixed. The American Graduate School of International Management "Thunderbird" (2003) states that there is also an effective exchange rate, which is a multilateral rate that measures the overall nominal value of the currency in the foreign exchange market.

The relationship between exchange rates and nominal interest rates is captured in two propositions: one the covered interest parity theorem (CIP) which deals with a no-arbitrage equilibrium in international financial markets, and the speculative efficiency hypothesis and the resulting uncovered parity theorem (UIP) which deals with a speculative equilibrium in international financial markets.

The three parities have been analysed very extensively using various methods; theoretical and empirical studies in this field are discussed at length in the meta-studies of MacDonald (1998) and Sarno (2002). The general upshot of this literature is that the parities, taken alone, seldom hold empirically in typical data samples. Only for very long time series, spanning a century or so, or for panel data of large dimensions can the parities be empirically verified.

As mentioned in Section 1, the empirical methodology in this paper follows the approach put forward by Juselius and MacDonald (2004a), who jointly scrutinize the international parity relations between Germany and the USA. Their analysis strongly rejects the stationarity of single parities, but by allowing the latter to be interrelated it recovers their stationarity. The authors also argue that the apparent nonstationarity of the simple parities is due to very slow adjustment to sustainable exchange rates.

The approach of Juselius and MacDonald is based on earlier work by Juselius (1990, 1992, \& 1995), Johansen and Juselius (1992), and MacDonald and Marsh (1997), and it was also applied to Japan vs. the USA by Juselius and MacDonald (2004b). Another important exception to the rule that empirical research in this area concentrates on only one of the parities is a recent paper by Lambelet and Mihailov (2005), who also model the three parities jointly using various single equation and system equation estimation methods. The authors refer to the parities as the triple parity law, stressing that they are closely interrelated. Robust evidence is found that the parities hold in the long run, on average, and ex post.

\section{Methodology and Model Specification}

The study used macroeconomic data including real GDP per-capita, external borrowing, the spot exchange rate (defined as local currency/US\$), the foreign country CPI, the foreign country lending rate, for the two countries covering a period of fifty years between 1961 and 2010.

The study employed Augmented Dickey Fuller (ADF) tests to test for stationarity of the three parity relations between the two countries. The Vector Autoregressive (VAR) model was estimated through which the three parity conditions were jointly modeled for joint cointegration analysis. The VAR model is preferred because it provides a systematic way to capture the presence of rich dynamics in multiple time series. 


\subsection{Model Specification for Stationarity Tests}

The model used in this study was adopted from (Stazka, 2008). First the Purchasing Power Parity (PPP) is tested. PPP is one of the most extensively studied relationships in the international economics. In its strong form it can be written as follows:

$$
P P P_{t}=P_{t}+P_{t}^{*}-S_{t}
$$

Where $P P P_{t}$ is the deviation from PPP, $P_{t}$ and $P_{t}{ }^{*}$ are, respectively, the domestic and the foreign price levels, and $S_{t}$ is the spot exchange rate (in price notation, i.e. the price of foreign currency in units of domestic currency). Empirically, the PPP condition is verified if $P P P_{t}$ is a stationary process.

Next the uncovered interest parity (UIP) relationship is examined:

$$
E_{t}\left(\Delta S_{t+m}\right)=I_{t m}-I_{t m^{*}}
$$

Where $E_{t}$ denotes the expected value given the information set available at time $t, \Delta$ is the difference operator and $I_{t m}$ and $I_{t m^{*}}$ are, respectively, the domestic and the foreign nominal treasury bills with maturity, $m$. Thus, the UIP postulates that the expected rate of denomination of the domestic currency should be equal to the home vs. foreign interest spread. Assuming rational expectations:

$$
\Delta S_{t+m}=E_{t}\left(\Delta S_{t+m}\right)+\varepsilon_{t+m}
$$

Where $\varepsilon_{t+m}$ is the error term

Combining (2) and (3) leads to:

$$
\Delta S_{t+m}-\left(I_{t m}-I_{t m^{*}}\right)=\varepsilon_{t+m}
$$

Under the assumption of rational expectations, testing the UIP amounts to testing whether $\varepsilon_{t+m}$ in (4) above is stationary.

The third parity relation of interest is the real interest parity (RIP):

$$
R_{t m}=R_{t m^{*}}
$$

In its testable version:

$$
R_{t m}-R_{t m^{*}}=V_{t m}
$$

Where $R_{t}$ and $R_{t m} *$ are the domestic and the foreign real treasury bills with maturity, $m$, respectively.

If the RIP holds, then $V_{t m}$ in (6), which is the empirically observed real interest differential between the home and foreign country, should be a stationary process.

A useful relation in international parity relations is the Fisher decomposition stating that the nominal interest yield is the sum of the real yield and the expected inflation rate over a given period $(t$ to $t+m)$ :

Using the Fisher decomposition, equation (6) can be rewritten in the following way:

$$
I_{t m}-I_{t m^{*}}=E_{t}\left(\Delta P_{t+m} \Delta P_{t+m^{*}}\right)+V_{t}
$$

Again assuming rational expectations:

$$
\left(I_{t m}-I_{t m^{*}}\right)-\left(\Delta P_{t+m} \Delta P_{t+m}\right)=V_{t}
$$

From equation (8) above the RIP holds empirically if the difference between the interest rate spread and the inflation differential is stationary.

\subsection{Cointegrated VAR Model Specification}

Following Juselius \& Macdonald $(2003,2005)$ the $j$-dimensional cointegrated VAR $(k)$ model is given by the following equation:

$$
\Delta X_{t}=\pi X_{t-l}+\Gamma_{l} \Delta X_{t+1}+\cdots+\Gamma_{k-1}+\Delta X_{t-k+1}+\Phi D_{t}+\varepsilon_{t}
$$

where $X_{t}$ is a $j x l$ vector of endogenous variables, $D_{t}$ is a $b x l$ vector of deterministic components (such as a constant, a linear time trend, seasonal or intervention dummies, or strictly exogenous variables), $\varepsilon_{t}$ is a vector of error terms, and $Л, \Gamma_{i}$ and $\Phi$ are coefficient matrices of appropriate dimension. Based on the assumption that all variables in (9) are at most $I(1)$, the cointegration hypothesis can be formulated as a reduced rank restriction on the matrix $J$ :

$$
\pi=\alpha \beta
$$

Where $\alpha$ and $\beta$ are $k$ coefficient matrices with full column rank and $r x j$, which implies that the rank of $J$ is also $r$. As the variables in $X_{t}$ are $I(1)$, their first differences on the left hand side of (10) are stationary; therefore, all terms on the right hand side of the equation must also be stationary. Thus, the matrix $\pi$ translates the non-stationary vector 
$t X_{t-1}$, into a stationary one $\pi X_{t-1}$. More precisely, it is the expression $\beta X_{t-1}$ that defines the stationary linear combinations (cointegration relations) of the $I(1)$ vector $X_{t-1,}$, whereas the matrix $\alpha$ describes how the variables in the system adjust to the equilibrium error from the previous period $\beta X_{t-1}$. The rank $r$ of the matrix $\pi$ gives the number of cointegration relations (steady states, long-run equilibrium relations) between the $j$ variables of the VAR system, whereas $j-r$ gives the number of common stochastic trends that drive their behaviour.

The analysis in the next section aims at finding cointegration relations between the variables of interest that can be given a meaningful economic interpretation, and at identifying the common stochastic trends.

The vector of variables that are relevant for this analysis is defined as follows:

$$
X_{t}=\left[\begin{array}{llllll}
P_{t} & P_{t}^{*} & I_{t} & I_{t} & * & S_{t}
\end{array}\right]
$$

Where: $P_{t}=$ the Kenyan ("home country") consumer price index,

$P_{t}^{*}=$ the Ugandan ("foreign country") consumer price index,

$I_{t}=$ the Kenyan 91 day Treasury bill rate,

$I_{t} *=$ the Ugandan 91 day Treasury bill rate,

$S_{t}=$ the spot exchange rate (defined as KES/UGX).

The data are monthly, and span the fifty years period between July 2005 and June 2010. All series are obtained from the Central Bank of Kenya for Kenya series and Bank of Uganda for Uganda series. The data in levels and in differences are depicted in Appendix 3 to Appendix 5 below.

Both the graphical analysis of the time series in the previous section and the formal tests to be discussed in the next section suggest that all the variables are $I(1)$. The transformed vector of variables whose joint behaviour is to be explained within the cointegrated VAR framework now becomes:

$$
\Delta X_{t}=\left[\begin{array}{llllll}
\Delta P_{t} & \Delta P_{t}^{*} & \Delta I_{t} & \Delta I_{t} * & \Delta P P P_{t}
\end{array}\right] \quad \sim I(1)
$$

Where $P P P_{t}$ is the deviation from PPP

The aim is to find out whether there exist stationary linear combinations of the simple parities. In other words, to find parameter values for $A, B$ and $C$ such that:

$$
A\left(\Delta I_{t}-\Delta I_{t}^{*}\right)-B\left(\Delta P_{t}-\Delta P_{t}^{*}\right)-C \Delta P P P_{t}
$$

define stationary equilibrium relations which pull the system variables whenever they are pushed away from equilibrium.

\subsection{Results of Empirical Analysis}

\subsubsection{Individual Parity Stationarity Test Results}

Based on ADF test, the series for deviation from PPP would be stationary at $1 \%, 5 \%$ or $10 \%$ level of significance if the calculated ADF statistic is less than the respective critical values of -3.5713 (for $1 \%$ level of significance), -2.5923 (for 5\% level of significance) and -2.599 (for 10\% level of significance). All the calculated ADF statistics except the ADF statistic showing RIP between Kenya and Uganda is significant at 5\% level of significance. From the analysis, the Purchasing Power Parity and Uncovered Interest Parity relationship does not hold between Kenya and Uganda. Only the real interest parity holds. The results are summarized in Appendix 1 below.

\subsubsection{Joint Cointegrated VAR Modeling Results}

The joint VAR modeling results suggest that the estimated VAR model satisfies the $I$ (1) assumptions, which postulate that: (1) the rank of the matrix $Л$ is equal to $r$, (2) the residuals are independent, (3) the sample size is large and (4) the parameters of the VAR model are stable throughout the sample.

The next step of analysis consisted of the determination of the cointegration rank, $r$, i.e. the number of steady-state relations between the variables of the system. The only formal test applied was the Johansen test, whose results show that the largest two eigenvalues are significantly different from zero at $5 \%$ significance level as summarized in Appendix II below.

The Johansen Cointegration test thus points to $r=3$. Thus, based on the Johansen Cointegration test the rank of the matrix $\pi$ and thus the number of steady-state relationships between the variables of interest is concluded to be equal to three. The L.R. test indicates 3 cointegrating equations at 5\% significance level. No restrictions were imposed on the VAR model.

The cointegration relations are defined as follows: 


$$
C R 1_{t}=\Delta P_{t}+1.034297 \Delta P_{t}^{*}-0.099945 \Delta I_{t} *-0.168381 \Delta I_{t}-0.997899 \Delta P P P_{t}-0.000411
$$

The log likelihood is 972.6986 whereas all the p-values for the coefficients indicate that the cointegration coefficients in equation (14) above are empirically identified - the coefficients which have not been set to zero are significantly different from zero as depicted by the p-values.

The reactions of the endogenous system variables to the departure from steady-states are plausible in the sense that the respective coefficients are significant, have the signs consistent with error-correcting behaviour and are of magnitude which by and large "makes sense". Based on this and from the economic point of view the cointegration relations indicate the following results: (1) The Ugandan price index $\left(P_{t}^{*}\right)$ is equilibrium-adjusting, i.e. if there is a positive departure from the above $\mathrm{CR} 1_{\mathrm{t}}$ equilibrium model then change in the Ugandan price index $\left(\Delta P_{t}^{*}\right)$ would increase in the next month correcting about $103 \%$ of the equilibrium error. This is a very fast adjustment as it implies that a $1 \%$ increase in the equilibrium model above would result in a $103 \%$ increase in the Uganda price index; (2) The above result is however the opposite of the departure from PPP correction. If there is a positive departure from the above $\mathrm{CR} 1_{\mathrm{t}}$ equilibrium model then change in the international fisher effect between Kenya and Uganda $\left(\triangle P P P_{t}\right)$ would fall in the next month correcting about $99.8 \%$ of the equilibrium error; (3) the Ugandan 91 treasury bill rate $\left(I_{t} *\right)$ is equilibrium-adjusting, i.e. if there is a positive departure from the above CR $1_{\mathrm{t}}$ equilibrium model then change in Ugandan T-bill rate $\left(\Delta I_{t}{ }^{*}\right)$ would fall in the next month correcting about $9.99 \%$ of the equilibrium error; and (4) it is interesting to note that the coefficient for dummies is less than $0.05 \%$; meaning that the endogenous variables explain more than $99.95 \%$ of the VAR model. This indicates a fast correction towards the long run equilibrium of the parity relations.

\section{Conclusion and Recommendations}

This paper tried to identify a set of economically meaningful long-run equilibrium relations that would reflect the international parity relations - the purchasing power parity, the uncovered interest parity and the real interest parity between Kenya and Uganda. As these parities seldom hold empirically, the general idea was to model them jointly in order to uncover the dynamic structure underlying the stochastic behaviour of prices, interest rates and the real exchange rate in Uganda versus Kenya. The empirical analysis, based on individual parity stationarity tests showed that the simple parities are inconsistent with the subject data set except for RIP.

Therefore, the question arises why the parities that are so well-established in the economic theory could not hold when analyzing the Kenya-Uganda data set. The rationale for this is in the fact that the sample was rather short, and covered the periods when both Uganda and Kenya were undergoing significant economic policy changes. Therefore, the parities which are supposed to hold in the long run could not (yet) be identified within the model. One has probably to wait several years (more than the fifty years in the model) before these long-run relations can actually be reflected in the data.

The analysis did establish a VAR model with reasonably stable parameters and remarkably well-behaved residuals, which led to meaningful conclusions about the stochastic behaviour of the variables. Meaningful long-run equilibrium relations that the system was adjusting to were identified: one depicting the interdependence of Kenya's and Uganda's inflation rates and exchange rate, partly the result of inflation expectations, and partly affected by the real exchange rate, and the other bringing together the domestic (Kenya's) real interest rate and the foreign (Uganda's) inflation. All the variables exhibit equilibrium-adjusting behaviour, i.e. they are pulled back to the steady-state once they have been pushed away from it.

Referring to the question asked in the introduction to this paper - whether the EAC is "ripe" for the common monetary policy - the answer is not a clear-cut "NO", despite the empirical failure of the individual parities. As the Kenya-Uganda inflation rates, interest rates, and the real exchange rate have followed a pattern that is consistent with long-run equilibrium-correcting behaviour, and because the estimated system shows such remarkable degree of stability, it can be argued that Uganda has shown a tendency to converge to Kenya both in nominal and in real terms. Therefore, one can conclude that in the long run the Kenyan and Ugandan economies can be integrated without fearing major turbulences.

\section{References}

Cheng, B. S. (1999). Beyond the purchasing power parity: Testing for cointegration and causality between exchange rates, prices and interest rates. Journal of International Money and Finance, 18, 911-924. http://dx.doi.org/10.1016/S0261-5606(99)00035-2

De Grauwe, P. (2003). Economics of Monetary Union (5th ed.). Oxford University Press, Oxford.

Eiteman, D. Stonehill, A., \& Moffett, M. (2007). Multinational Business Finance (11th ed.). Pearson Addison, Wesley. 
Franco, B. (2006). Random walks and cointegration relationships in international parity conditions between Germany and USA for the post Bretton-Woods period. MERIT, Maastricht University LEM, Laboratory of Economics and Management, Sant'Anna School of Advanced Studies, Pisa.

Franco, B., \& Daraio, C. (2001). International parity relationships between Germany and US: a multivariate time series analysis for the post Bretton-Woods period. LEM Working Paper Series, Sant'Anna School of Advanced Studies.

Jean-François, H. (2009). Does long-run purchasing power parity hold in Eastern and Southern African countries? Evidence from panel data stationary tests with multiple structural breaks. International Journal of Finance and Economics, 15(4), 307-315.

Johansen, S. (1995). Identifying Restrictions of Linear Equations. With Applications to Simultaneous Equations and Cointegration. Journal of Econometrics, 69(1), 111-132. http://dx.doi.org/10.1016/0304-4076(94)01664-L

Johansen, S. (1996). Likelihood-Based Inference in Cointegrated Vector Autoregressive Models ( $2^{\text {nd }}$ Ed.) Advanced Texts in Econometrics, Oxford University Press, Oxford.

Johansen, S., \& Juselius, K. (1992). Testing Structural Hypotheses in a Multivariate Cointegration Analysis of the PPP and the UIP for the UK. Journal of Econometrics, 53(1), 211-244. http://dx.doi.org/10.1016/0304-4076(92)90086-7

Juselius, K. (1990). Long-Run Relations in a Well Defined Statistical Model for the Data Generating Process. Cointegration Analysis of the PPP and the UIP Relations. Discussion Paper, No. 90-1, University of Copenhagen. Department of Economics, Copenhagen.

Juselius, K. (1992). On the Empirical Verification of the Purchasing Power Parity and the Uncovered Interest Rate Parity. Nationalo konomisk Tidsskrift, 130(1), 57-66.

Juselius, K. (1995). Do the Purchasing Power Parity and the Uncovered Interest Rate Parity Hold in the Long Run? An Application of Likelihood Inference in a Multivariate Time Series Model. Journal of Econometrics, 69(1), 211-240. http://dx.doi.org/10.1016/0304-4076(94)01669-Q

Juselius, K. (2006). The Cointegrated VAR Model: Methodology and Applications. Oxford University Press, Oxford.

Juselius, K., \& MacDonald, R. (2004a). International Parity Relationships Between Germany and the United States: A Joint Modeling Approach. Working Paper. No. 2004/08, University of Copenhagen, Department of Economics, Finance Research Unit, Copenhagen.

Juselius, K., \& MacDonald, R. (2004b). International Parity Relationships between the USA and Japan. Japan and the World Economy, 16(1), 17-34. http://dx.doi.org/10.1016/S0922-1425(03)00003-3

Kenen, P. (1969). The Theory of Optimum Currency Areas: An Eclectic View. in: R. A. Mundell, A.K. Swoboda (ed.), Monetary Problems of the International Economy. University of Chicago Press, Chicago.

Lambelet, J., \& Mihailov, A. (2005). The Triple-Parity Law. Discussion Paper, No. 604, University of Essex Economics, Essex. http://dx.doi.org/10.1080/09539960500334087

MacDonald, R., \& Marsh, I. (1997). On Fundamentals and Exchange Rates: A Casselian Perspective. Review of Economics and Statistics, 78, 655-664. http://dx.doi.org/10.1162/003465397557060

MacDonald, R., \& Marsh, I. (1999). Exchange Rate Modeling. Kluwer Academic Publishers.

McKinnon, R. (1963). Optimum Currency Areas. The American Economic Review, 53(4), 717-725.

Mishkin, F. (1982). Are real Interest Rates equal across Countries? An Empirical Investigation of International Parity Conditions. National Bureau of Economic Research. Massachusetts.

Mongelli, F. (2005). What is European Economic and Monetary Union Telling us About the Properties of Optimum Currency Areas? Journal of Common Market Studies, 43(3), 607-635. http://dx.doi.org/10.1111/j.0021-9886.2005.00571.x

Mundell, R. (1961). A Theory of Optimum Currency Areas. The American Economic Review, 51(4), 657-665.

Sarno, L., \& Taylor, M. (2002). The Economics of Exchange Rates. Cambridge University Press, Cambridge.

Sosvilla-Riviero, S., \& Garcia, E. (2003). Purchasing Power Parity Revisited. Working Paper for Foundation for Applied Economic Research (FEDEA).

Stazka, A. (2008). International parity relations between Poland and Germany: a cointegrated VAR approach. Munich Personal RePEc Archive.

World Bank Publication. (2010). Kenya Economic Update. December 2010 issue. 
Appendix 1. Stationarity (ADF) test results

\begin{tabular}{lccc}
\hline Kenya & PPP ADF tests & UIP ADF tests & RIP ADF tests \\
\hline \multirow{3}{*}{ Uganda } & -0.1418 & -1.2763 & $\mathbf{- 2 . 2 5 0 3 *}$ \\
& $(0.8879)$ & $(0.2084)$ & $(0.0294)$ \\
\hline
\end{tabular}

Critical values for rejection of hypothesis of a unit root:

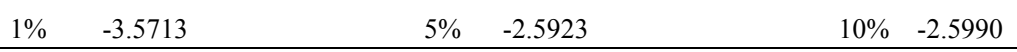

The table shows ADF results. The ADF statistics are shown first in the cells. *ADF statistics for stationary RIP at $5 \%$ level of significance is denoted in bold. The order of the series is shown last in the cells. The values in brackets denote the p-values for the ADF test

Appendix 2. Johansen cointegration test results

\begin{tabular}{|c|c|c|c|c|c|}
\hline Eigenvalue & $\begin{array}{l}\text { Likelihood } \\
\text { Ratio }\end{array}$ & $\begin{array}{l}5 \text { Percent } \\
\text { Critical Value }\end{array}$ & $\begin{array}{l}1 \text { Percent } \\
\text { Critical Value }\end{array}$ & $\begin{array}{l}\text { Hypothesized } \\
\text { No. of CE(s) }\end{array}$ & \\
\hline 0.446793 & 90.80299 & 68.52 & 76.07 & None ** & \\
\hline 0.355797 & 57.64974 & 47.21 & 54.46 & At most $1 * *$ & \\
\hline 0.286944 & 33.02423 & 29.68 & 35.65 & At most $2 *$ & \\
\hline 0.188938 & 14.08529 & 15.41 & 20.04 & At most 3 & \\
\hline 0.041238 & 2.358311 & 3.76 & 6.65 & At most 4 & \\
\hline \multicolumn{6}{|c|}{$*(* *)$ denotes rejection of the hypothesis at $5 \%(1 \%)$ significance level } \\
\hline \multicolumn{6}{|c|}{ L.R. test indicates 3 cointegrating equation(s) at $5 \%$ significance level } \\
\hline \multicolumn{6}{|c|}{ Normalized Cointegrating Coefficients: 1 Cointegrating Equation(s) } \\
\hline QCPI_KE & QCPI_UG & QPPT & QTBILLR_KE & QTBILLR_UG & $\mathrm{C}$ \\
\hline \multirow[t]{2}{*}{1.000000} & 1.034297 & -0.997899 & -0.168381 & -0.099945 & -0.000411 \\
\hline & $(0.01952)$ & $(0.00127)$ & $(0.05787)$ & $(0.02436)$ & \\
\hline Log likelihood & 972.6986 & & & & \\
\hline
\end{tabular}

The table shows the Johansen cointegration results

Appendix 3. Data in levels
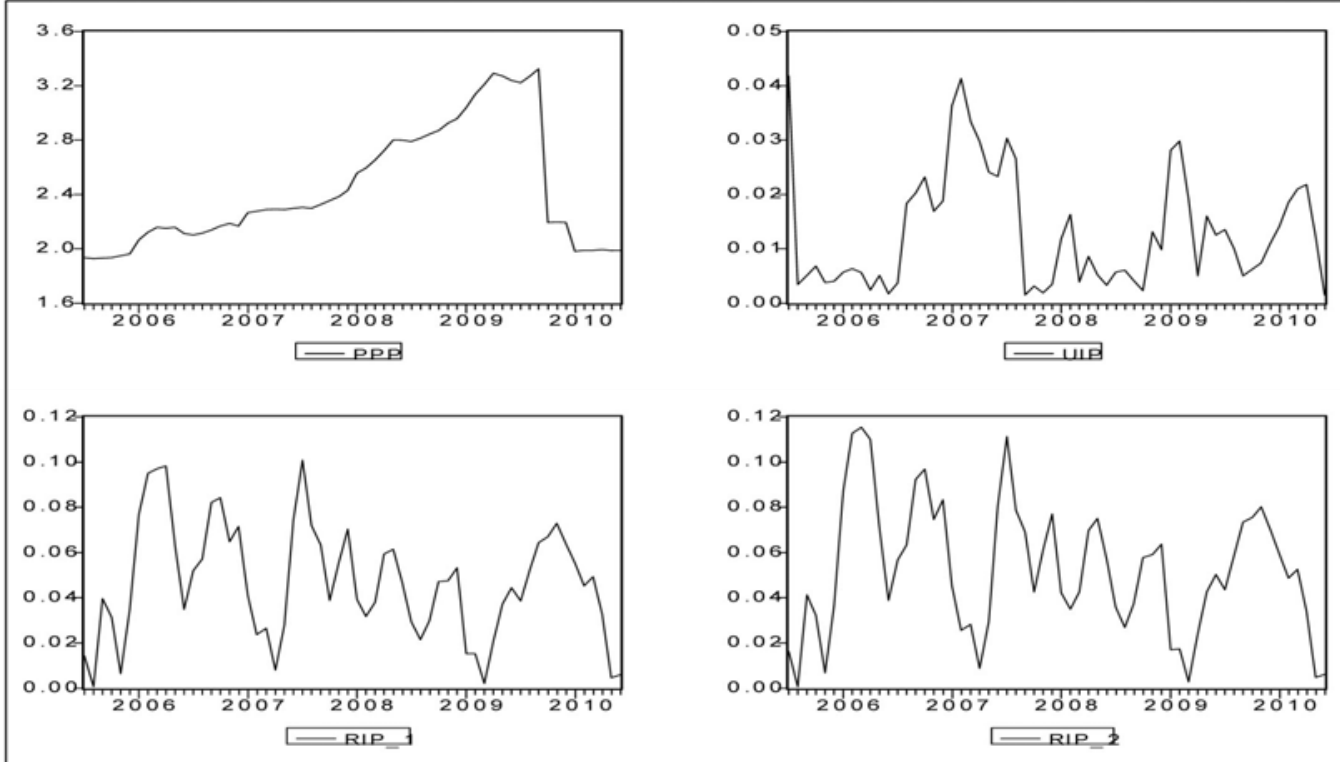

The above figure shows the series for data in levels. PPP, UIP and RIP stands for Purchasing Power Parity, Uncovered Interest Parity and Real Interest Parity 
Appendix 4. Data in first difference

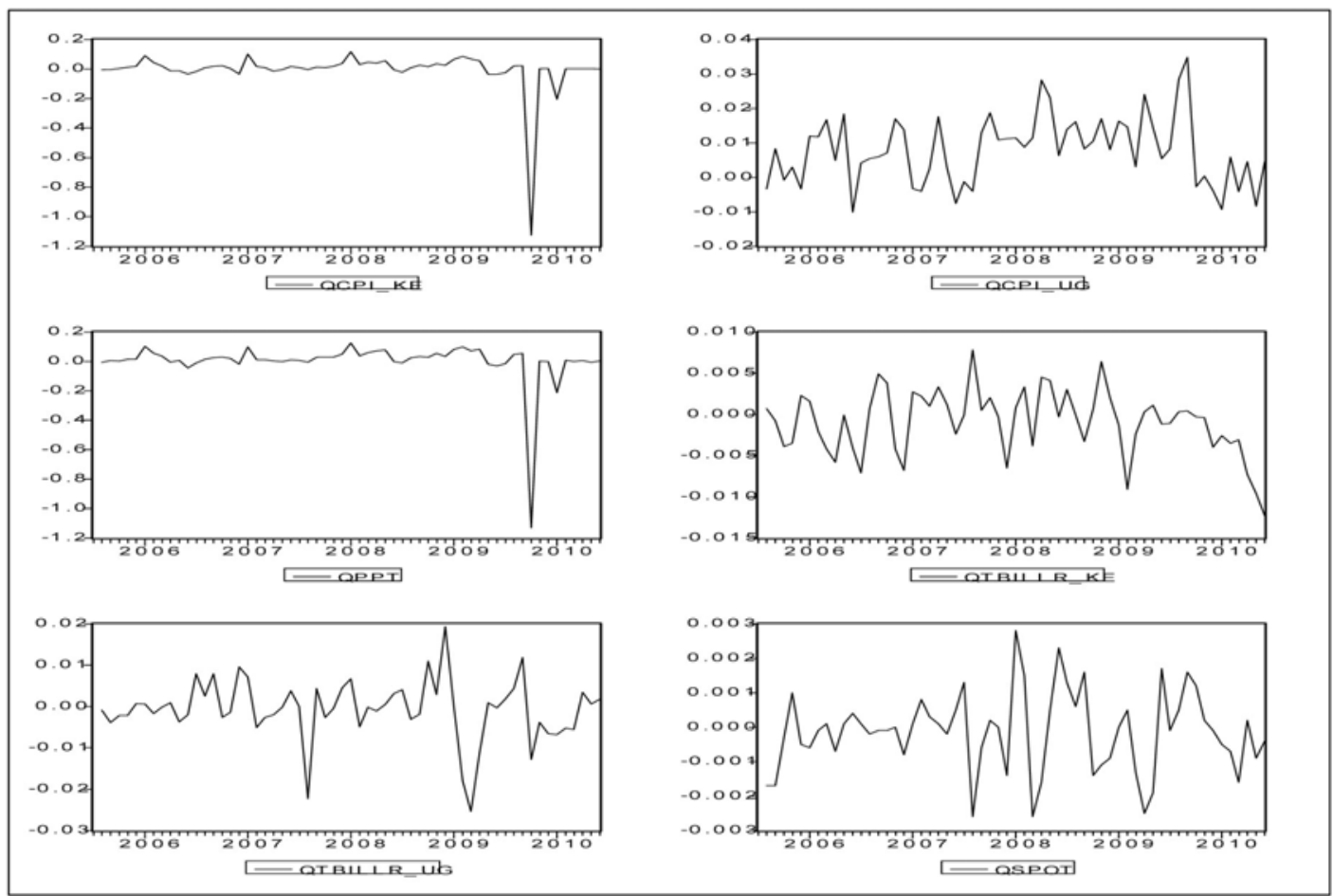

The above figure shows the series for data in differenced once for the Kenya and Uganda CPI, T-Bill rates and exchange rates.

Appendix 5. Data in second difference

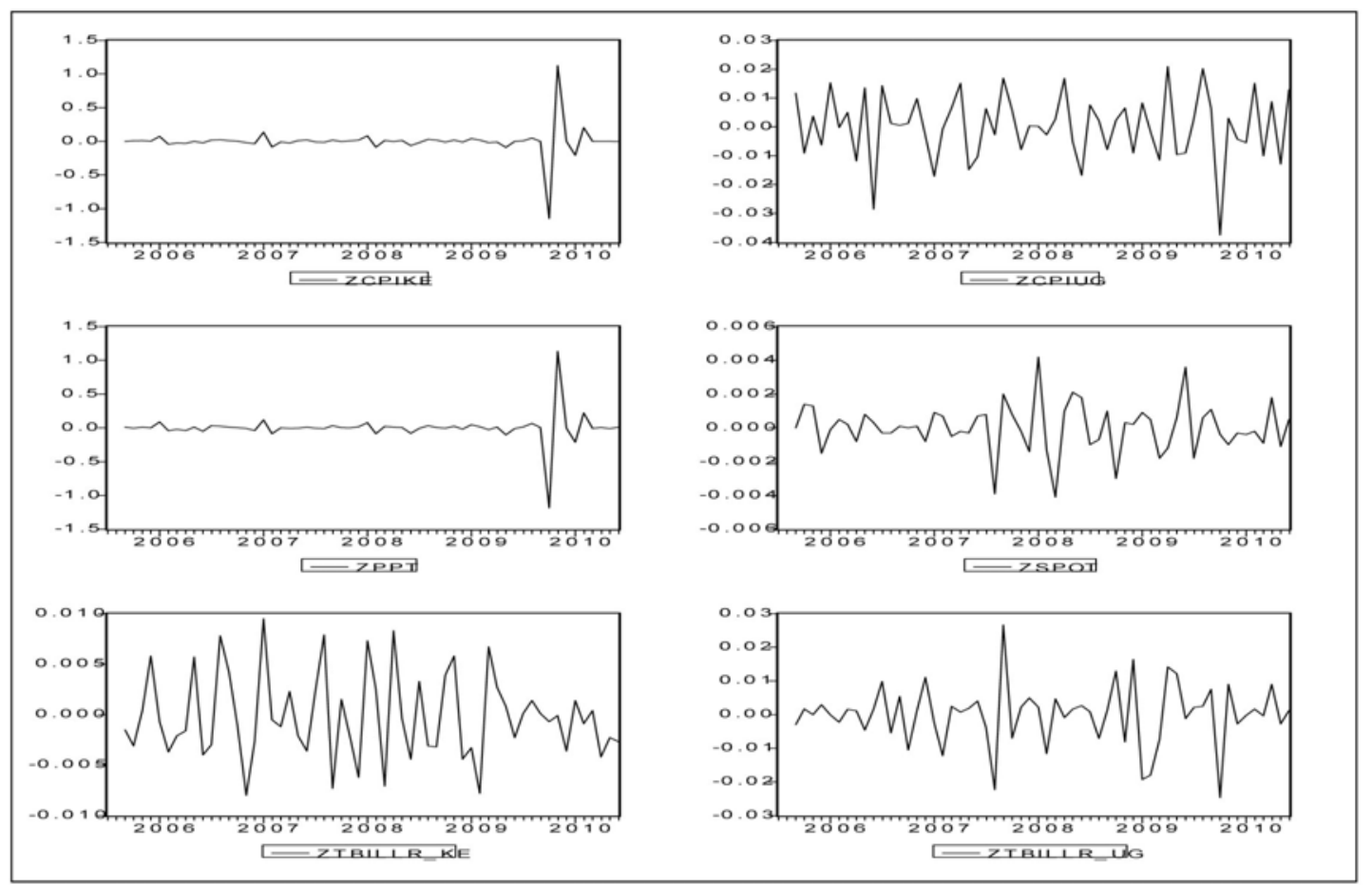

The above figure shows the series for data in differenced twice for the Kenya and Uganda CPI, T-Bill rates and exchange rates. 